\title{
Role of PKC-ERK signaling in tamoxifen-induced apoptosis and tamoxifen resistance in human breast cancer cells
}

\author{
ZHIHUA LI ${ }^{1,3^{*}}$, NA WANG $^{1,4^{*}}$, JIEYU FANG $^{2}$, JINTAO HUANG $^{1}$, FEN TIAN $^{1}$, CHAOHONG LI $^{1}$ and FUKANG XIE ${ }^{1}$ \\ ${ }^{1}$ Department of Histology and Embryology, Zhongshan School of Medicine, Sun Yat-Sen University, Guangzhou, Guangdong; \\ ${ }^{2}$ Department of Anesthesiology, The First Affiliated Hospital of Sun Yat-Sen University, Guangzhou, Guangdong, P.R. China
}

Received December 2, 2011; Accepted February 28, 2012

DOI: $10.3892 /$ or.2012.1728

\begin{abstract}
This study was designed to investigate the role of protein kinase $\mathrm{C}(\mathrm{PKC})$ and extracellular signal-regulated kinase 1/2 (ERK1/2) signaling in tamoxifen (TAM)-induced apoptosis and drug resistance in human breast cancer cells. Drug-sensitive, or estrogen receptor (ER)-positive human breast carcinoma cells (MCF-7) and the multi-drug-resistant variant (ER-negative) MCF-7/ADR cells were treated with doses of TAM for various periods of time. Cell viability and apoptosis were assessed using cell counting, DNA fragmentation and flow cytometric analysis. We found that TAM administration caused a significant increase in apoptosis of MCF-7 cells but not MCF-7/ADR cells. Western blot analysis revealed enhanced expression of $\mathrm{PKC} \delta$ but decreased expression of PKC $\alpha$ in ER-positive MCF-7 cells; while ER-negative MCF-7/ADR cells had decreased levels of PKC $\delta$ and increased levels of PKC $\alpha$. Interestingly, we observed that in MCF-7 cells, TAM stimulated apoptosis by promoting rapid activation of PKCס, antagonizing downstream signaling of ERK phosphorylation; while in MCF-7/ADR cells, TAM upregulated
\end{abstract}

Correspondence to: Professor Fukang Xie, Department of Histology and Embryology, Zhongshan School of Medicine, Sun Yat-Sen University, 74 Zhongshan Second Avenue, Guangzhou, Guangdong 510080, P.R. China

E-mail: frankxie200@yahoo.com

Present addresses: ${ }^{3}$ The Third Affiliated Hospital of Guangzhou Medical College, Guangzhou, Guangdong 510150; Key Laboratory for Major Obstetric Diseases of Guangdong Province, Guangzhou; ${ }^{4}$ State Key Laboratory of Biocontrol, School of Life Sciences, Sun Yat-sen (Zhongshan) University (East Campus), Guangzhou, P.R. China

*Contributed equally

Abbreviations: TAM, tamoxifen; ER, estrogen receptor; SERM, selective estrogen receptor modulator; ERK1/2, extracellular signalregulated kinase 1/2; PKC, protein kinase $\mathrm{C}$; MAPKs, mitogen-activated protein kinases; FBS, fetal bovine serum; EDTA, ethylenediamine tetraacetic acid; SDS, sodium dodecyl sulfate; PBS, phosphate-buffered saline; DMSO, dimethyl sulfoxide; PI, propidium iodide

Key words: MCF-7, MCF-7/ADR, apoptosis, drug resistance, tamoxifen, protein kinase $\mathrm{C}$, extracellular signal-regulated kinase
PKC $\alpha$, which promoted ERK phosphorylation. These results suggest that PKCס enhances apoptosis in TAM-treated MCF-7 cells by antagonizing ERK phosphorylation; while the PKC $\alpha$ pathway plays an important role in TAM-induced drug resistance by activating ERK signaling in MCF-7/ADR cells. The combination of TAM with PKC $\alpha$ and ERK inhibitors could promote TAM-induced apoptosis in breast cancer cells.

\section{Introduction}

Breast cancer is a common malignancy in females and the second cause of death from cancer in women today (1). Treatment for breast cancer includes surgery, chemotherapy, radiotherapy and endocrine therapy. Tamoxifen (TAM), an antagonist of the estrogen receptor (ER), is a selective ER modulator (SERM). TAM is a front-line endocrine therapeutic drug for ER-positive breast cancers. Results from TAM therapy showed a $40-50 \%$ reduction in the risk of cancer recurrence and cancer mortality (2). Recently, TAM has been demonstrated to be effective for some ER-negative breast cancers, as well as other types of cancers, including gliomas. These data suggest that TAM may also be implicated in ER-independent antitumor mechanisms $(3,4)$. Of note, some advanced breast cancers that initially respond well to TAM eventually become refractory to treatment (5-9). Thus, the traditional mechanism of TAM action through the ER is challenged, and other noncanonical pathways need to be explored.

Protein kinase C (PKC), a family of serine/threonine kinases, is involved in many important cellular functions, including cell proliferation, migration, differentiation, and apoptosis (10-12). Twelve PKC isoforms have been discovered in various cell types, including conventional PKCs (cPKC $\alpha$, $\beta \mathrm{I} / \beta \mathrm{II}$ and $\gamma$ ), novel PKCs (nPKC $\delta, \varepsilon, \eta)$, and atypical PKCs $(\mathrm{aPKC} \zeta)(13,14)$. The expression of PKC $\alpha, \delta, \varepsilon, \eta, \gamma, \mu$, and $\zeta$ has been detected in MCF-7 cells $(15,16)$; PKC $\alpha$ is a marker for anti-estrogen resistance and is involved in the growth of TAM-resistant human breast cancer cells $(17,18)$. Overexpression of $\mathrm{PKC} \alpha$ stimulates the proliferation of MCF-7 cells and C6 glioma cells $(14,19)$. PKC $\delta$ controls cellular proliferation, differentiation, migration and apoptosis in various cell types $(13,21,22)$, representing the predominant isoform expressed in MCF-7 cells (20). Studies of PKC $\delta$ in estrogen-responsive tissues have been contradictory. PKC $\delta$ increased proliferative and survival capacities in an immortal- 
ized mammary cell line (23). Estrogen has been reported to stimulate the expression of PKCס in the corpus luteum (24), but to downregulate the expression of PKC 8 in MCF-7 cells (20). A small molecule PKC $\delta$ inhibitor or a dominant-negative PKC $\delta$ mutant impaired phorbol ester-induced cell arrest in the G1 phase in SKRB-3 breast cancer cells (25). Alternatively, some studies have suggested that PKC $\delta$ could act as a positive regulator of growth in tumor-derived mammary cells, potentially through activating the mitogenic Ras/extracellular signal-regulated kinase 1/2 (ERK1/2) pathway $(26,27)$. A prosurvival role for PKC $\delta$ in breast cancer cells has also been reported $(22,28)$.

The mitogen-activated protein kinase (MAPK) superfamily consists of four major sets of kinases: the extracellular-receptor kinases (ERK), c-jun N-terminal or stress-activated protein kinases (JNK/SAPK), ERK5/big MAP kinase 1 (BMK1), and the $\mathrm{p} 38$ protein kinases (29). Growth factor-regulated gene transcription and cell proliferation are blocked in mammalian cells when MAPK activity is inhibited (30-32), indicating that MAPKs are necessary for cell growth. Inhibition of ERK signaling using a MEK inhibitor, PD98059, induced apoptosis in MCF-7 cells $(33,34)$. ERK activation was inversely correlated with apoptosis $(35,36)$. Activation of ERK by TAM has previously been shown in HeLa cells (37) and human endometrial cancer cells (38). Recently, TAM was shown to activate ERK in ER-positive MCF-7 and T47D cells but not in ER-negative MDA-MB-231 cells (39). Katayama et al (40) suggested that blockade of the MEK-ERK-RSK pathway suppressed cell surface P-glycoprotein expression by promoting its degradation, leading to decreased multidrug resistance (MDR).

Drug resistance is a major clinical limitation for the successful management of breast cancers (42-45). In the present study, we investigated the mechanisms of TAM-induced apoptosis and drug resistance using MCF-7 cells and its multidrug-resistant variant, MCF-7/ADR cells.

\section{Materials and methods}

Reagents. RPMI-1640 and phenol red-free RPMI-1640 were purchased from Gibco-BRL (Grand Island, NY, USA). TAM, rottlerin, and PD98086 were obtained from Sigma-Aldrich (St. Louis, MO), dissolved in dimethyl sulfoxide (DMSO) at $10 \mathrm{mM}$ and stored at $-20^{\circ} \mathrm{C}$. Gö6976 (Calbiochem, San Diego, CA, USA) was dissolved in DMSO at $1 \mathrm{mM}$ and stored at $-20^{\circ} \mathrm{C}$. Rabbit polyclonal antibodies specific for phospho-PKC $\alpha, \mathrm{PKC} \alpha, \mathrm{PKC} \delta, \mathrm{ERK}$, and $\beta$-actin and a mouse monoclonal antibody specific for phospho-ERK were obtained from Cell Signaling Technology (Beverly, MA, USA); the rabbit polyclonal phospho-PKC $\delta$ antibody was from Santa Cruz Biotechnology, Inc. (Santa Cruz, CA, USA); and HRP-conjugated secondary antibodies (anti-mouse and antirabbit) were from QED, Biovision, Inc. (Hercules, CA, USA). The enhanced chemiluminescence (ECL) kit was purchased from GE Healthcare (USA).

Cell lines and cell cultures. Human breast carcinoma MCF-7 cells and their multidrug resistant variant, MCF-7/ADR cells, were kindly provided by Professor Wenlin Huang (Sun Yat-Sen University, China). The cells were maintained in RPMI-1640 supplemented with $10 \%$ fetal bovine serum (FBS), $100 \mathrm{U} / \mathrm{ml}$ of penicillin, and $100 \mu \mathrm{g} / \mathrm{ml}$ of streptomycin under standard incubation conditions (humidified atmosphere, 95\% air, 5\% $\mathrm{CO}_{2}, 37^{\circ} \mathrm{C}$ ). Cells were passaged every 3 days at a ratio of $1: 3$ using $0.125 \%$ trypsin- $0.02 \%$ EDTA. For experiments, cells in the third to fourth passage were used. Cells of $5 \times 10^{5} / 90-\mathrm{mm}$ dish or $10^{5}$ cells/60-mm dish were cultured in phenol red-free RPMI-1640 supplemented with 10\% dextran-coated charcoal (DCC)-FBS according to the protocol of Migliaccio et al (46). Following $24 \mathrm{~h}$ culture in estrogen-depleted medium, the cells were starved overnight with phenol red-free RPMI-1640 containing 1\% DCC-FBS, followed by additions of TAM, rottlerin, Gö6976 or PD98059 at the indicated concentrations. After washing with phosphate-buffered saline (PBS), the cells were collected at the time points indicated.

Cell death analysis. To evaluate the effects of TAM on cancer cell death, cells were plated at a density of $5 \times 10^{5}$ cells $/ \mathrm{ml}$ in 60 -mm cell culture plates. Following starvation with phenol redfree RPMI-1640 containing 1\% DCC-FCS for $24 \mathrm{~h}$, cells were treated with various concentrations $(1,5,10$ or $20 \mu \mathrm{M})$ of TAM at the indicated time periods $(1,3,6,12$ and $24 \mathrm{~h})$. Thereafter, cells were trypsinized with trypsin-EDTA, stained with trypan blue solution $(0.04 \% \mathrm{w} / \mathrm{v})$, and counted using a hemocytometer. The number of dead or live cells was calculated in each sample, and vehicle controls (0.1\% DMSO) were included in each experiment. Each experiment was performed in triplicate.

Detection of apoptotic cells. MCF-7 and MCF-7/ADR cells were grown in 6-well plates at a density of 10,000/well. After treatment with $10 \mu \mathrm{M}$ of TAM for $24 \mathrm{~h}$, the cells were fixed in $4 \%$ paraformaldehyde for $15 \mathrm{~min}$ at room temperature, permealized with $0.1 \%$ Triton X-100 (Sigma-Aldrich) for $30 \mathrm{~min}$, rinsed with PBS and incubated for $5 \mathrm{~min}$ at room temperature with $0.01 \%$ DAPI stain (Sigma-Aldrich). Excessive stain was removed by washing the cells with PBS. Nuclei were visualized using a Leica fluorescence microscope. The cells with condensed and/ or fragmented nuclei were scored as apoptotic cells.

DNA fragmentation (DNA ladders). To confirm TAM-induced apoptosis, DNA fragmentation was performed in TAM-treated cells as previously described (47). In brief, cells that were treated with TAM for different periods of time were collected and digested in $500 \mu \mathrm{l}$ of lysis buffer $(10 \mathrm{mM}$ Tris, $\mathrm{pH} 7.5$; $25 \mathrm{mM}$ EDTA; $1 \%$ SDS; $100 \mathrm{mM} \mathrm{NaCl}$ ) for $15 \mathrm{~min}$ at room temperature. Lysed cells were then treated with $1 \mathrm{mg} / \mathrm{ml}$ of proteinase $\mathrm{K}$ (final concentration $100 \mu \mathrm{g} / \mathrm{ml}$ ), and incubated at $56^{\circ} \mathrm{C}$ for $30 \mathrm{~min}$. DNA was extracted twice with phenol/chloroform/isoamyl alcohol (25:24:1) and chloroform prior to $1.5 \%$ agarose electrophoresis. DNA ladders in the gel were detected using GoldView staining (SBS Genetech, China) under UV illumination.

Quantification of apoptosis by flow cytometry. Cells were treated with 5,10 or $20 \mu \mathrm{M}$ of TAM or $0.1 \%$ DMSO as a control for $24 \mathrm{~h}$. The cells were then harvested using trypsinEDTA and were fixed in $70 \%$ cold ethanol overnight. The cells were subsequently treated with propidium iodide $(50 \mathrm{mg} / \mathrm{ml})$ and RNase $(20 \mathrm{mg} / \mathrm{ml})$ for $15 \mathrm{~min}$ and analyzed using a flow cytometer (Beckman Coulter) equipped with an air-cooled argon ion laser emitting at a wavelength of $488 \mathrm{~nm}$ at $15 \mathrm{~mW}$. 

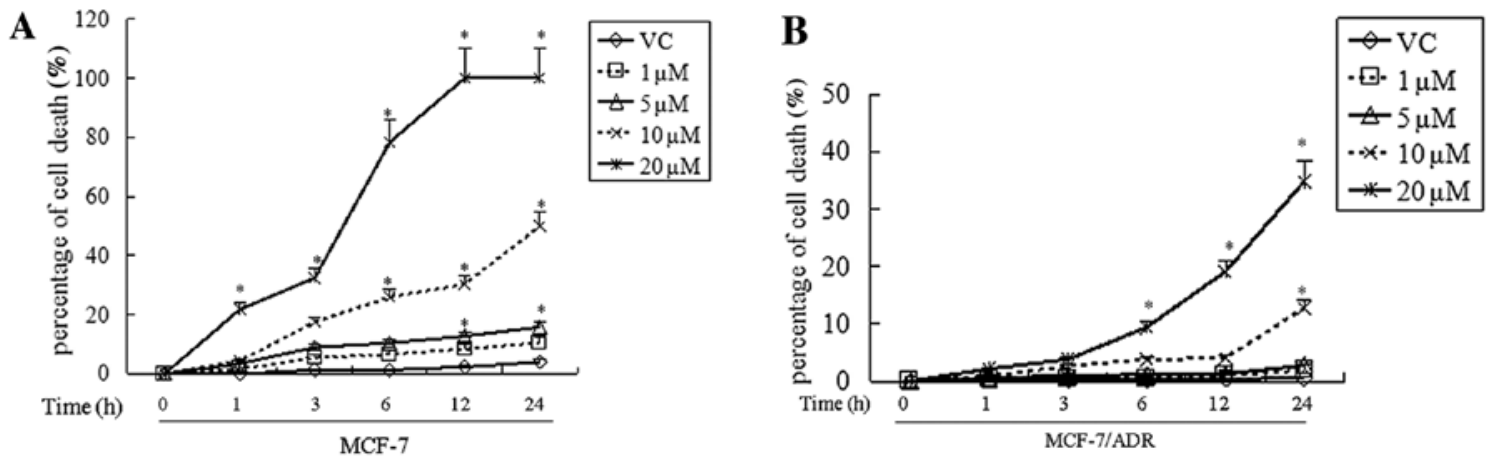

Figure 1. Time course of TAM-induced cell death in breast cancer cells. MCF-7 and MCF-7/ADR cells were treated with 5-20 mM TAM or vehicle control (VC, $0.1 \%$ DMSO) for $1,3,6,12$ or $24 \mathrm{~h}$ followed by staining with trypan blue. Numbers of dead and live cells were counted using a hemocytometer. (A) Cell death curve for MCF-7 cells; (B) cell death curve for MCF-7/ADR cells. Data are the percentage of cell death (mean \pm SD, $n=3)$. ${ }^{*}<<0.05$ compared to vehicle control.

DNA histograms were assessed using the Beckman Coulter cytometry software from a minimum of 10,000 events/sample. To detect the effect of signaling inhibitors, cells were pretreated with $100 \mathrm{nM}$ of Gö6976, $10 \mu \mathrm{M}$ of rottlerin, or $20 \mu \mathrm{M}$ of PD98059 for $1 \mathrm{~h}$ prior to treatment with or without $20 \mu \mathrm{M}$ TAM for $24 \mathrm{~h}$ and harvested for flow cytometric analysis of apoptosis. All experiments were performed in triplicate.

Western blot analysis. Western blot analyses were performed as previously described (48). In brief, protein extracts were obtained by lysing $5 \times 10^{6}$ cells in buffer A $(20 \mathrm{mM}$ HEPES, $\mathrm{pH} 7.4,2 \mathrm{mM}$ EDTA, $50 \mathrm{mM} \beta$-glycerophosphate, $1 \mathrm{mM}$ dithiothreitol, $1 \mathrm{mM} \mathrm{Na} \mathrm{VO}_{4}, 1 \%$ Triton, $10 \%$ glycerol) supplemented with protease inhibitors $(4 \%)$ for $15 \mathrm{~min}$ on ice followed by sonication for $10 \mathrm{sec}$. Protein concentration was determined using the Bio-Rad DC protein assay kit (Bio-Rad Laboratories, Hercules, CA, USA). Samples (60 $\mu \mathrm{g}$ ) were denatured for $10 \mathrm{~min}$ in boiling water, followed by electrophoresis on $12 \%$ SDS-polyacrylamide gels and transferred onto nitrocellulose membranes (Pall Corporation, Ann Arbor, MI, USA) using electroblotting. Membranes were probed with antibodies as indicated (non-specific binding was blocked by incubation in TBS with $5 \%$ non-fat dry milk), followed by incubation with HRP-conjugated rabbit or mouse secondary antibodies. Detection was performed using enhanced chemiluminescence (Amersham) on Hyperfilm (Fuji, Japan) according to the manufacturer's instructions. The same blots were subsequently stripped and re-blotted with corresponding pan antibodies, and membranes were re-probed with a $\beta$-actin antibody as the loading control. For quantification, band intensities were quantified using GeneSnap (SynGene, Cambridge, UK) software and normalized to the corresponding total ERK or $\beta$-actin levels.

Data analyses. Each experiment was performed in triplicate, and the data were expressed as mean \pm SD. Statistical analyses were performed utilizing the SPSS 11.5 software. Student's t-test and ANOVA were used in this study. Differences were considered significant when the P-values were $<0.05$.

\section{Results}

TAM induces cell death in MCF-7 and MCF-7/ADR cells. To explore the effect of TAM on cell death of breast cancer cells, MCF-7 or MCF-7/ADR cells were incubated in phenol red-free
RPMI-1640/1\% DCC-FBS in the presence of 1,5, 10 or $20 \mu \mathrm{M}$ of TAM for $1,3,6,12$ or $24 \mathrm{~h}$. Control vehicle cells were treated with $0.1 \%$ DMSO only. As shown in Fig. 1, the number of dead MCF-7 cells increased in a time- and dose-dependent manner in the presence of TAM (Fig. 1A). Treatment with $10 \mu \mathrm{M}$ of TAM for $24 \mathrm{~h}$ resulted in a $49 \%$ of cell death in MCF-7 cells, but only $15 \%$ of cells were dead in TAM-treated MCF-7/ADR cells (Fig. 1B). The proportion of dead cells was nearly $100 \%$ in MCF-7 cells following treatment with $20 \mu \mathrm{M}$ TAM (Fig. 1A); while the dead cell proportion was only $35 \%$ in MCF-7/ADR cells (Fig. 1B). These data demonstrate that MCF-7 cells are susceptible to cell death induced by TAM, with the $\mathrm{IC}_{50}$ of TAM in MCF-7 cells at approximately $10 \mu \mathrm{M}$; while MCF-7/ADR cells are resistant to TAM.

TAM induces cell death in breast cancer cells via apoptosis. Since cell death includes necrosis and apoptosis (49), we examined whether TAM induced cell death breast cancer via an apoptotic pathway. Multiple nucleosome fragments, DNA gel electrophoresis and flow cytometry were performed in TAM-treated MCF-7 and MCF-7/ADR cells. As shown in Fig 2A, typical apoptotic bodies were observed in MCF-7 cells treated with $10 \mu \mathrm{M}$ of TAM for $24 \mathrm{~h}$, while few apoptotic bodies appeared in the MCF-7/ADR cells. To further confirm apoptosis in these cells, genomic DNA was extracted from TAM-treated cells and was subjected to $1.5 \%$ agarose gel electrophoresis. As shown in Fig. 2B, DNA fragmentation became apparent in MCF-7 cells in response to $10 \mu \mathrm{M}$ of TAM exposure, with $\sim 65 \%$ of MCF-7 cells undergoing apoptosis (Fig. 2B and C). In addition, DNA fragmentation increased in a dose-dependent manner (Fig. 2B). When cells were treated with $10 \mu \mathrm{M}$ TAM for 12 to $72 \mathrm{~h}$, DNA ladders were visible in MCF-7 cells, and the ladders gradually increased in a timedependent manner and peaked at $72 \mathrm{~h}$ (Fig. 2B). Interestingly, no DNA fragmentation was detected in TAM-treated MCF-7/ ADR cells, except for the positive control cells (Fig. 2B), and the percentage of apoptotic cells in MCF-7/ADR cells was significantly lower compared to that in MCF-7 cells (Fig. 2C-D). These results suggest that TAM-induced cell death in breast cancer is predominantly due to apoptosis, and MCF-7/ADR cells are resistant to TAM.

Differential expression and phosphorylation of $P K C \alpha, P K C \delta$, and ERK in MCF-7 and MCF-7/ADR cells treated with 

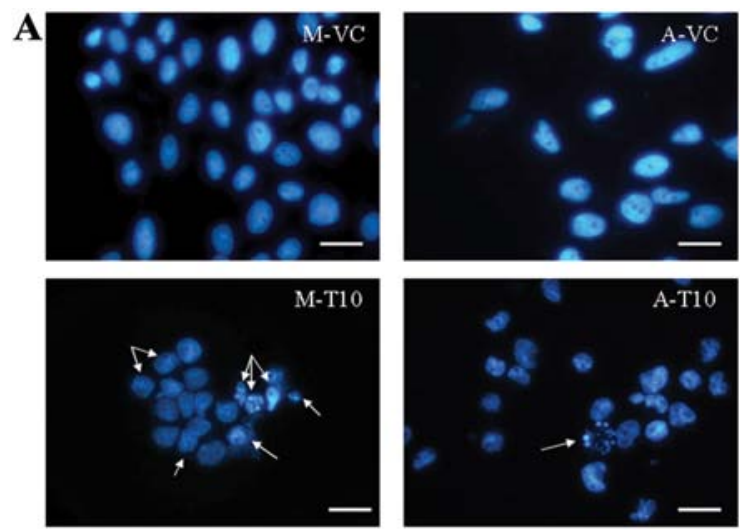

C
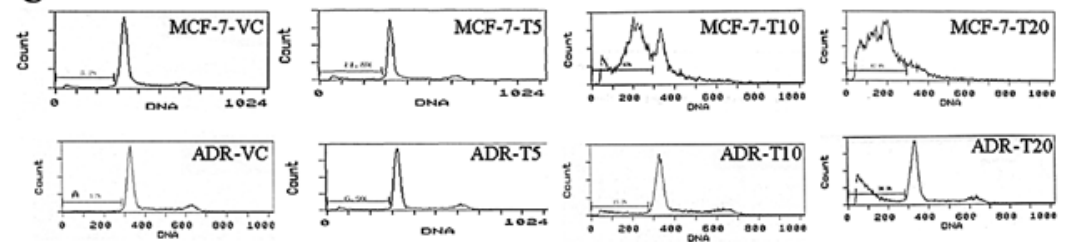
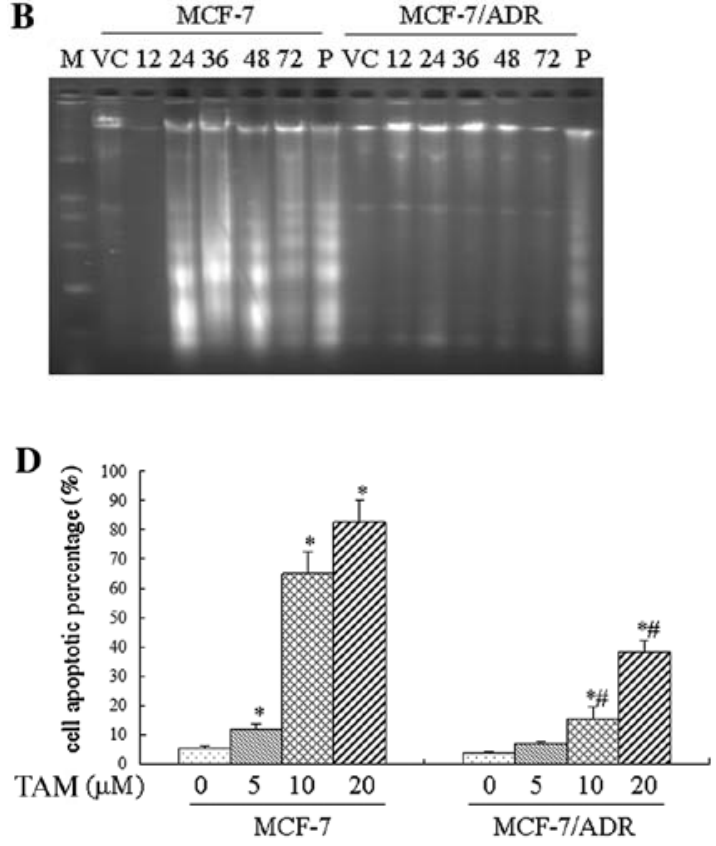

Figure 2. TAM-induced apoptosis in the MCF-7 and MCF-7/ADR cells. MCF-7 and MCF-7/ADR cells grown on 60-mm dishes (5x10 5 cells/dish) were treated with various concentrations of TAM for $24 \mathrm{~h}$ or with $10 \mathrm{mM}$ of TAM for the indicated time periods prior to analyses as described in the Materials and methods section. (A) DAPI staining; (B) DNA fragmentation; (C) cell apoptotic histograms using flow cytometric analysis; and (D) statistical graph of cell apoptosis. M, DNA marker; ADR, MCF-7/ADR; VC, vehicle control; T5, TAM $5 \mu \mathrm{M}$; T10, TAM $10 \mu \mathrm{M}$; T20, TAM $20 \mu \mathrm{M}$; P, positive control, where cells were treated with $5 \mathrm{M} \mathrm{H}_{2} \mathrm{O}_{2}$. Data are representative of three independent experiments; ${ }^{*} \mathrm{P}<0.05$ TAM-treated cells compared to VC; ${ }^{\mathrm{P}}<0.05$ TAM-treated $\mathrm{MCF}-7$ cells compared to MCF-7/ADR cells.

TAM. To explore the possible signaling pathways involved in TAM-induced apoptosis in MCF and MCF-7/ADR cells, we investigated the expression of $\mathrm{PKC} \alpha, \mathrm{PKC} \delta$ and $\mathrm{ERK}$ and their phosphorylation in TAM-treated cells. MCF-7 and MCF-7/ADR cells were treated with $10 \mu \mathrm{M}$ of TAM for 10-60 min. Our results suggested increased PKC $\delta$ and decreased PKC $\alpha$ expression in MCF-7 cells, while in MCF-7/ ADR cells, we found decreased PKC $\delta$ and increased PKC $\alpha$ expression (Fig. 3A-D) $(\mathrm{P}<0.05)$. Interestingly, TAM induced a rapid activation of $\mathrm{PKC} \delta$ in MCF-7 cells in a time-dependent manner with the peak PKC $\delta$ activation detected at $60 \mathrm{~min}$ (Fig. 3C and D). Conversely, TAM stimulated PKC $\alpha$ phosphorylation in MCF-7 cells at $10 \mathrm{~min}$, which was maintained up to $15 \mathrm{~min}$. The phosphorylation level of PKC $\alpha$ began to decrease from 30 to $60 \mathrm{~min}$, although the level of PKC $\alpha$ at these time points was still much higher compared to that in the vehicle control $(\mathrm{P}<0.05)$. In MCF-7/ADR cells, the basal level of PKC $\alpha$ phosphorylation was high, TAM treatment did not further alter their phosphorylation (Fig. 3A and B).

To assess the relationship between the PKC and MAPK families in breast cancer cells, we investigated ERK expression and its activation. As shown in Fig. 3E and F, p-ERK1/2 started to increase 10 min following TAM exposure in MCF-7/ ADR cells, and gradually increased in a time-dependent manner. However, in MCF-7 cells, ERK was only slightly activated at $30 \mathrm{~min}$, with prominent phosphorylation of ERK1/2 observed at $60 \mathrm{~min}$ following TAM treatment. These data suggest that TAM-induced apoptosis in MCF-7 cells may be mediated through activation of $\mathrm{PKC} \alpha, \mathrm{PKC} \delta$ and ERK; while the PKC $\alpha$-ERK pathway promotes drug resistance in $\mathrm{MCF}-7 /$ ADR cells.
Impact of specific inhibitors of $P K C \alpha, P K C \delta$ and $E R K$ on TAM-treated MCF-7 and MCF-7/ADR cells. To determine how PKC and ERK could promote both TAM-induced apoptosis and resistance, we utilized PKC and ERK inhibitors. Cells were pretreated with specific signaling inhibitors (Gö6976, $100 \mathrm{nM}$; rottlerin, $10 \mu \mathrm{M}$; PD98059, $20 \mu \mathrm{M}$ ) for $1 \mathrm{~h}$ and were then exposed to $10 \mu \mathrm{M}$ of TAM for $24 \mathrm{~h}$ prior to flow cytometric analyses. As shown in Fig. 4, the PKC $\delta$ inhibitor, rottlerin, clearly reduced TAM-induced apoptosis. MCF-7 cells demonstrated a $10.3 \pm 3.1 \%$ reduction, and MCF-7/ADR cells showed a $5.1 \pm 2.0 \%$ decrease in apoptosis $(\mathrm{P}<0.05)$. Alternatively, we found that the PKC $\alpha / \beta$ isozyme pharmacological antagonist, Gö6976 and the MAP kinase inhibitor, PD98059 increased the rate of apoptosis in breast cancer cells. These inhibitors increased cell apoptosis by $20 \%$ and $13 \%$ in TAM-treated MCF-7 and MCF-7/ADR cells, respectively. These results suggest that PKC $\delta$ promotes TAM-induced apoptosis in MCF-7 cells, while PKC $\alpha$ and ERK protect breast cancer cells from death.

Effect of rottlerin and PD98059 on the expression and phosphorylation of PKC $\delta$ and ERK in TAM-treated MCF-7 cells. To investigate the relationship between PKC $\delta$ and ERK, we further assessed the impact of rottlerin and PD98059 on PKC $\delta$ and ERK activation. MCF-7 cells were pretreated with $10 \mu \mathrm{M}$ of rottlerin or $20 \mu \mathrm{M}$ of PD98059 for $1 \mathrm{~h}$ followed by $10 \mu \mathrm{M}$ of TAM for 30 or $60 \mathrm{~min}$. As shown in Fig. 5, rottlerin inhibited PKC $\delta$ phosphorylation and increased activation of ERK in TAM-treated MCF-7 cells. Alternatively, PD98059 inhibited ERK activation but had no effect on PKCס phosphorylation. These results indicate that TAM-induced apoptosis in MCF-7 cells may be mediated via activation of PKC $\delta$ and the subsequent inhibition of ERK. 

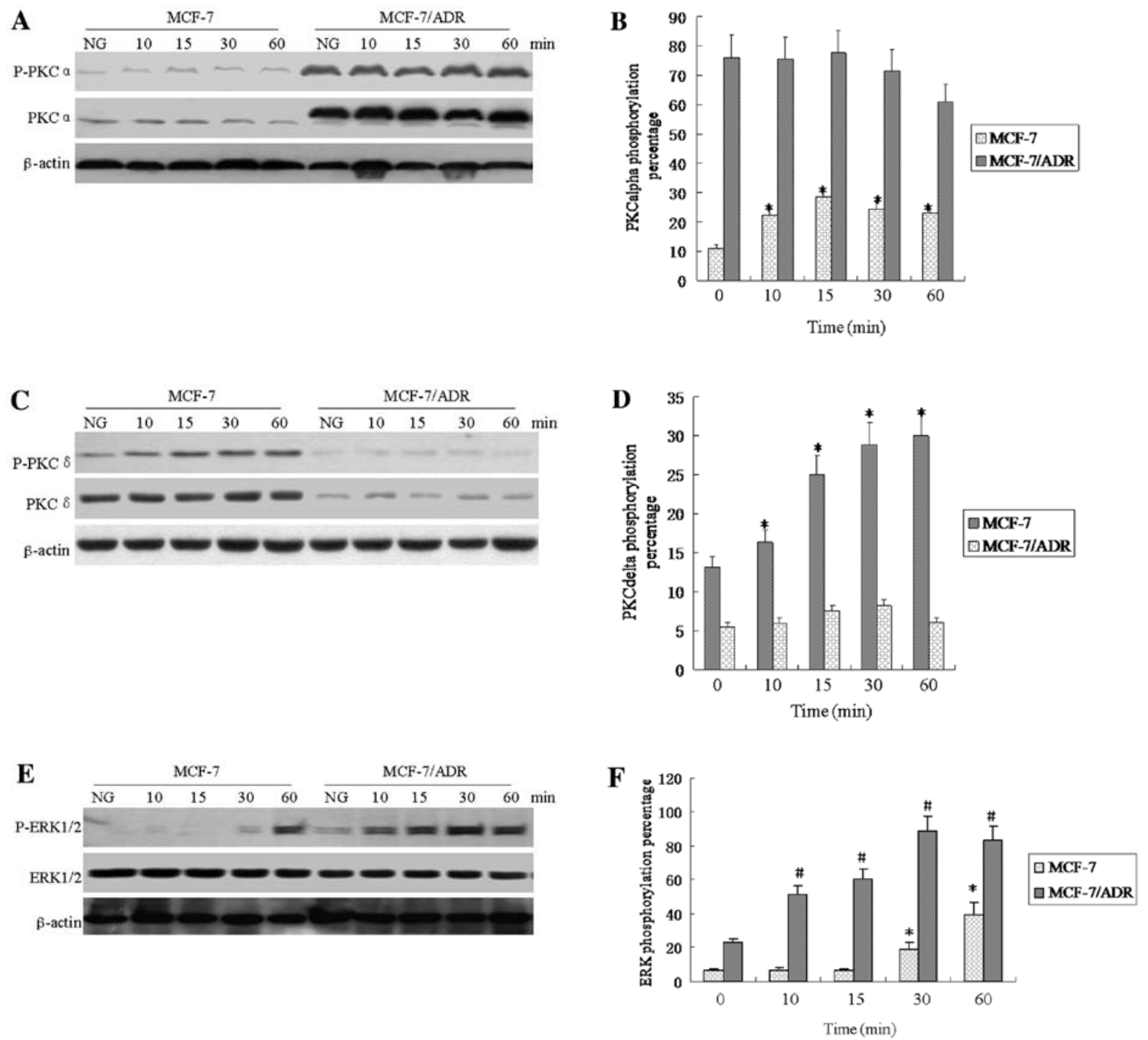

Figure 3. Differential expression and phosphorylation of PKC and ERK in MCF-7 and MCF-7/ADR cells. Cells were treated with or without $10 \mu \mathrm{M}$ of TAM (VC, $0.1 \%$ DMSO) for various time points prior to lysis. Lysate of $60 \mu \mathrm{g}$ from each sample was loaded onto $12 \%$ SDS gels. P-PKC $\alpha$, P-PKCd, and P-ERK were evaluated using western blot analysis. The same membrane was re-probed using PKC $\alpha$, PKC $\delta$ and ERK following stripping. (A) PKC $\alpha$ expression and phosphorylation; and (B) the ratio of P-PKC $\alpha$ to that of total PKC $\alpha$; (C) PKC $\delta$ expression and phosphorylation; and (D) the ratio of P-PKC $\delta$ to that of total PKC ; (E) the expression and phosphorylation of ERK; and (F) the ratio of P-ERK to that of total ERK. Data are representatives of three independent experiments (mean $\pm \mathrm{SD}$ ). ${ }^{*} \mathrm{P}<0.05$ TAM-treated cells compared to VC for MCF-7 cells; ${ }^{*} \mathrm{P}<0.05$ TAM-treated compared to VC for MCF-7/ADR cells.
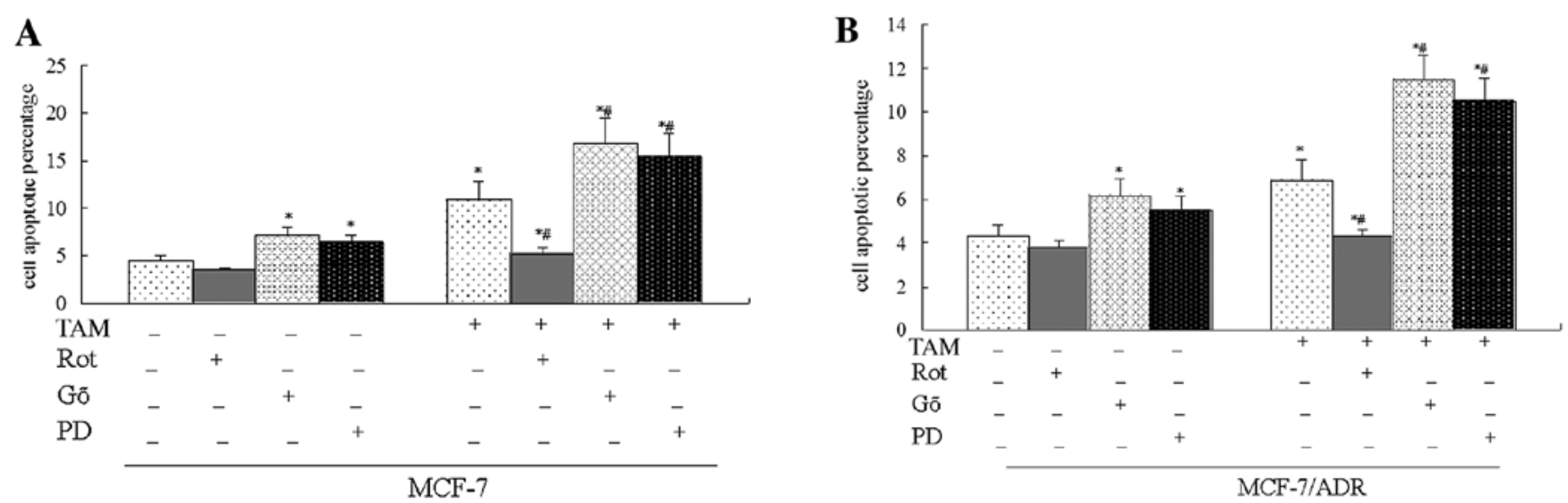

Figure 4. The effect of PKC and ERK inhibitors on TAM-induced apoptosis in MCF-7 and MCF-7/ADR cells. MCF-7 and MCF-7/ADR cells were pretreated with the PKC $\alpha$ inhibitor Gö6976 (Gö, $100 \mathrm{nM}$ ), the PKC inhibitor rottlerin (Rot, $10 \mu \mathrm{M}$ ), or the ERK inhibitor PD98059 (PD, $20 \mu \mathrm{M})$ for $1 \mathrm{~h}$ followed by $10 \mu \mathrm{M}$ of TAM (or DMSO) exposure for $24 \mathrm{~h}$ prior to cell collection and flow cytometry analyses. Cell apoptosis in (A) MCF-7 and (B) MCF-7/ADR. Data are mean $\pm \mathrm{SD}(\mathrm{n}=3)$ representative of three independent experiments that yielded similar results. ${ }^{*} \mathrm{P}<0.05$ compared to vehicle control; ${ }^{*} \mathrm{P}<0.05$ significantly different from the TAM treatment alone. 

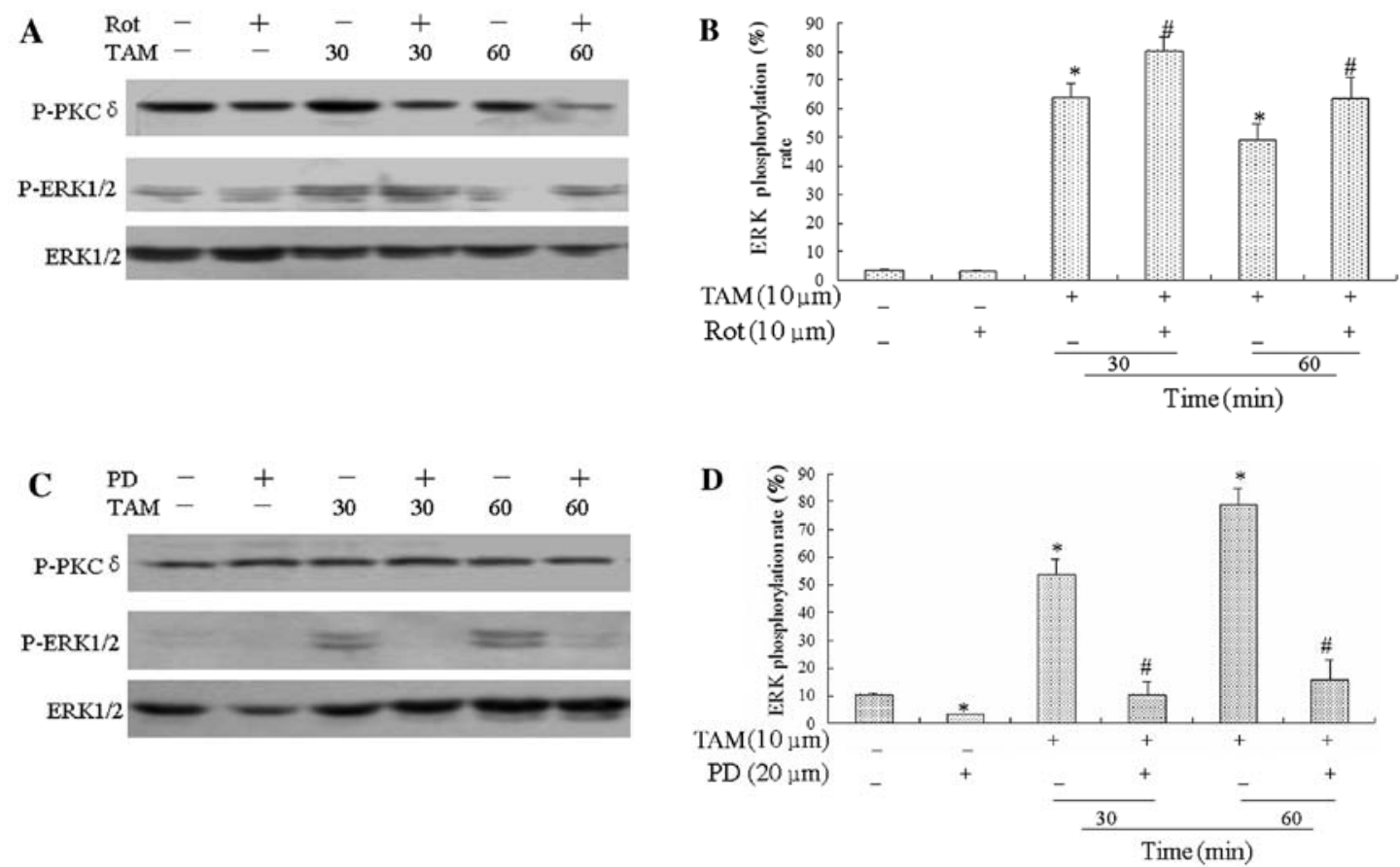

Figure 5. Effect of rottlerin (Rot) or PD98059 on PKCD and ERK activation in TAM-treated MCF-7 cells. MCF-7 cells were pretreated with or without $10 \mu \mathrm{M}$ of Rot or $20 \mu \mathrm{M}$ of PD98059PD for $1 \mathrm{~h}$ followed by $10 \mu \mathrm{M}$ of TAM exposure for different time periods. A total of $60 \mu \mathrm{g}$ of lysates from each sample was loaded onto 12\% SDS gels. P-PKC $\delta$ and P-ERK were evaluated using western blot analysis. The same membrane was re-probed for ERK following stripping. PKC $\delta$ and ERK phosphorylation and expression in MCF-7 cells after TAM treatment with or without (A and B) Rot or (C and D) PD and representation of the ratio of P-ERK to total ERK. Data are representative of three independent experiments (mean $\pm \mathrm{SD}$ ). ${ }^{*} \mathrm{P}<0.05$ compared to $0.1 \%$ DMSO treatment; ${ }^{*} \mathrm{P}<0.05$ compared to TAM treatment.
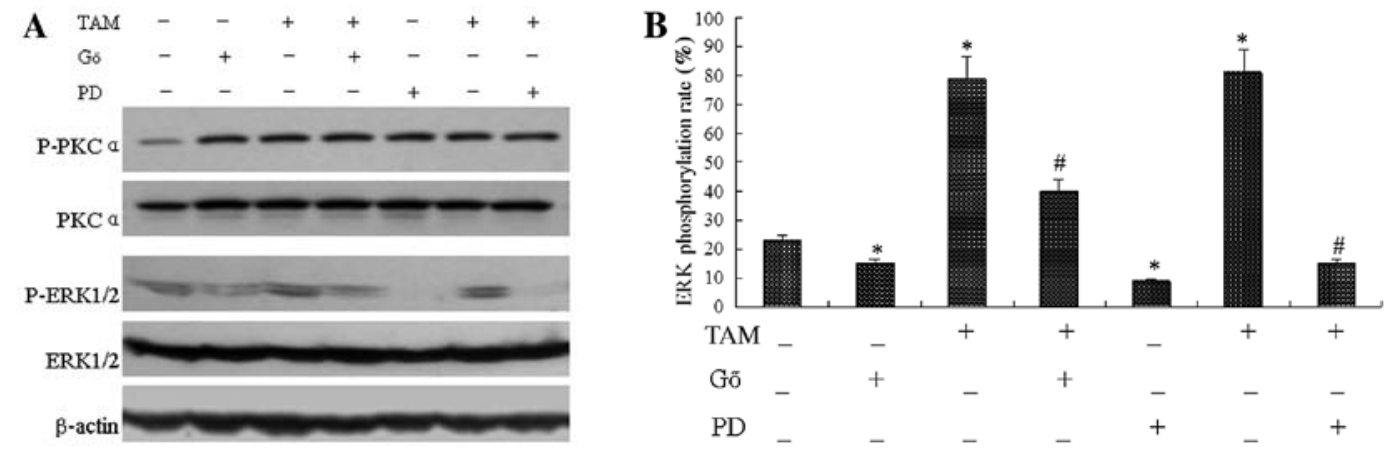

Figure 6. The effect of signaling inhibitors on the expression and phosphorylation of PKC $\alpha$ and ERK in MCF-7/ADR cells. The MCF-7/ADR cells were pretreated with or without $100 \mathrm{nM}$ of Gö6976 or $20 \mu \mathrm{M}$ of PD98059 for $1 \mathrm{~h}$ followed by $10 \mu \mathrm{M}$ of TAM exposure for $15 \mathrm{~min}$. Lysates of $60 \mu \mathrm{g}$ from each sample was loaded onto $12 \%$ SDS gels. P-PKC $\alpha$ and P-ERK were evaluated using western blot analysis. The same membrane was re-probed for PKC $\alpha$ and ERK following stripping. Protein loading was assessed by stripping the membrane and re-probing with a $\beta$-actin antibody. (A) PKC $\alpha$ and ERK phosphorylation and the expression in MCF-7/ADR cell; (B) ERK phosophorylation rate. Data are representative of three independent experiments (mean \pm SD). ${ }^{*} \mathrm{P}<0.05$ compared to $0.1 \%$ DMSO control; ${ }^{*} \mathrm{P}<0.05$ compared to TAM treatment alone.

Effect of Gö6976 and PD98059 on the expression and phosphorylation of PKC $\alpha$ and ERK in TAM-treated MCF-7/ADR cells. As demonstrated by flow cytometry, both Gö6976 and PD98059 enhanced the TAM-induced apoptosis in MCF-7/ ADR cells. We then determined how the expression and phosphorylation of PKC and ERK were regulated. We pretreated the MCF-7/ADR cells with or without $100 \mathrm{nM} \mathrm{Gö6976} \mathrm{or}$ $20 \mu \mathrm{M}$ PD98059 for $1 \mathrm{~h}$ followed by $10 \mu \mathrm{M}$ TAM exposure for 15 min. As shown in Fig. 6, both Gö6976 and PD98059 inhibited TAM-induced ERK phosphorylation in MCF-7/ADR cells; however, PD98059 had no effect on PKC $\alpha$ activity. We therefore, hypothesize that ERK may act downstream of PKC $\alpha$, cooperating together on TAM resistance in MCF-7/ADR cells.

\section{Discussion}

Growing evidence on the mechanism of TAM-induced cancer inhibition have led to the discovery of many signaling intermediates that may play critical roles in this process (50). However, mechanisms underlying TAM-induced apoptosis and TAM resistance are still not completely understood. In the present study, we determined for the first time that TAM was involved in both apoptotic and anti-apoptotic signaling pathways in breast cancer cells. We found that PKC $\delta$ phosphorylation participated in TAM-induced apoptosis in MCF-7 cells by antagonizing downstream ERK signaling; while in MCF-7/ ADR cells, PKC $\alpha$ activated downstream ERK signaling 
and promoted drug resistance. Our results also revealed that Gö6976 and PD98059 could promote TAM-induced apoptosis in these cells.

In breast cancer, TAM results in either a cytostatic end point (cell growth arrest) at nanomolar (nM) or a cytotoxic end point (cell death leading to tumor shrinkage and regression in vivo) at micromolar $(\mu \mathrm{M})$ concentrations (41). We observed that TAM-induced cell death in MCF-7 cells was dose- and time-dependent. However, in MCF-7/ADR cells, even with high concentrations and long term exposure of TAM (10 $\mu \mathrm{M}$, for $72 \mathrm{~h}$ ), the rate of apoptosis was still very low, implying that MCF-7/ADR cells were resistant to TAM.

There are many contradictory data on the pro-apoptotic or pro-survival effects of PKC $\delta(16,22,25)$. PKC $\delta$ has been reported to protect RAW264.7 macrophages from nitric oxideinduced apoptosis (51). PKCס increased mammary tumor cell growth and metastasis by activation of the Ras/ERK1/2 pathway (27). In this study, TAM stimulated PKC 8 activation in MCF-7 cells. The PKCס specific inhibitor, rottlerin, prevented TAM-induced apoptosis by inhibiting PKC $\delta$ phosphorylation and elevating p-ERK; while the ERK inhibitor, PD98059 increased apoptosis, but had no effect on PKC $\delta$ activation in these cells, indicating that ERK is the downstream mediator of PKC $\delta$. Our results are different from a report by Greco et al (52) in which they suggest that $\mathrm{PKC \delta / \varepsilon}$ mediated the PKC/Akt-dependent phosphorylation of ERK in MCF-7 cells, and led to cell proliferation. It is therefore possible that the activation of PKC $\delta$ by various factors may lead to divergent signaling pathways.

$\mathrm{PKC} \alpha$ is associated with cell proliferation in various cell types (53-55). Several lines of evidence indicate that inhibition of PKC $\alpha$ is sufficient to induce apoptosis, suggesting that PKC $\alpha$ functions to suppress apoptosis in some cells $(56,57)$. Overexpression of PKC $\alpha$ has been reported to promote the progression of breast cancer and reduce the expression of ER in MCF-7 cells (58). Interestingly, we observed that p-PKC $\alpha$ was overexpressed in the ER-negative MCF-7/ADR cells; it is possible that the high level of endogenous PKC $\alpha$ in MCF-7/ADR cells contributes to TAM resistance. In the present study, we also found that TAM promoted ERK activation in MCF-7/ADR cells, and both Gö6976 and PD98059 enhanced TAM-induced apoptosis by inhibiting ERK phosphorylation, however, these inhibitors did not alter PKC $\alpha$ activation, indicating that ERK was the downstream mediator of PKC $\alpha$ and participated in the drug resistance of MCF-7/ADR cells. These results are in accordance with a previous study suggesting that PKC counteracts apoptosis by acting on downstream effectors (the MAPK pathway) in Jurkat T cells $(59,60)$. Lin et al $(61)$ also found that MAPK activation promoted $\beta$-estradiol-induced breast carcinoma cell proliferation. Conversely, Fujii et al (25) reported that the antineoplaston A10 arrested SKBR-3 cells in the G1 phase via PKC $\alpha$ and MAPK; and $\mathrm{Wu}$ and Huang (62) reported that $\mathrm{PKC} \alpha$ is specifically required for TPA-induced ERK (MAPK) signaling, leading to inhibition of HepG2 cell growth.

In summary, our present results suggest that the PKC-ERK pathway plays an important role in mediating TAM-induced apoptosis as well as TAM resistance in breast cancer cells. PKC $\delta$ phosphorylation promoted TAM-induced apoptosis in MCF-7 cells by antagonizing ERK activation, while PKC $\alpha$ was involved in TAM resistance by activating downstream
ERK signaling in MCF-7/ADR cells. Therefore, combinations of TAM with Gö6976 and PD98059 could promote TAM-induced apoptosis in breast cancer cells and reduce TAM resistance.

\section{Acknowledgements}

This study was supported by grants from the CMB (98-677 to F.X.) and the National Nature Science Foundation of China (30570762 to C. Li). We thank Dr Qingyu Kong for technical support in fluorescence activated cell-sorting and Professor Guoquan Gao for providing the Gene Genius Bio-imaging System to analyze our western blotting results. We also thank the Medjaden Bioscience Limited for assisting in the preparation of this manuscript.

\section{References}

1. Shibuya K, Mathers CD, Boschi-Pinto C, Lopez AD and Murray CJ: Global and regional estimates of cancer mortality and incidence by site: II. Results for the global burden of disease 2000. BMC Cancer 26: 37, 2002.

2. Gerl R and Vaux DL: Apoptosis in the development and treatment of cancer. Carcinogenesis 26: 263-270, 2005.

3. Tian F, Wu H, Li Z, Wang N, Huang J, Li C and Xie F: Activated PKCalpha/ERK1/2 signaling inhibits tamoxifen-induced apoptosis in C6 cells. Cancer Invest 27: 802-808, 2009.

4. Todorova VK, Kaufmann Y, Luo S and Klimberg VS: Tamoxifen and raloxifene suppress the proliferation of estrogen receptornegative cells through inhibition of glutamine uptake. Cancer Chemother Pharmacol 67: 285-291, 2011.

5. Lazarus P, Blevins-Primeau AS, Zheng Y and Sun D: Potential role of UGT pharmacogenetics in cancer treatment and prevention: focus on tamoxifen. Ann NY Acad Sci 1155: 99-111, 2009.

6. McDonnell DP and Norris JD: Connections and regulation of the human estrogen receptor. Science 296: 1642-1644, 2002.

7. Jordan VC: Selective estrogen receptor modulation: concept and consequences in cancer. Cancer Cell 5: 207-213, 2004.

8. Howell A, Bundred NJ, Cuzick J, Allred DC and Clarke R: Response and resistance to the endocrine prevention of breast cancer. Adv Exp Med Biol 617: 201-211, 2008.

9. Shou J, Massarweh S, Osborne CK, Wakeling AE, Ali S, Weiss H and Schiff R: Mechanisms of tamoxifen resistance: increased estrogen receptor-HER2/neu cross-talk in ER/HER2-positive breast cancer. J Natl Cancer Inst 96: 926-935, 2004.

10. Clemens MJ, Trayner I and Menaya J: The role of protein kinase $\mathrm{C}$ isoenzymes in the regulation of cell proliferation and differentiation. J Cell Sci 103: 881-887, 1992.

11. Hug $H$ and Sarre TF: Protein kinase $C$ isoenzymes: divergence in signal transduction? Biochem J 291: 329-343, 2005.

12. Tanaka Y,Gavrielides MV,Mitsuuchi Y,Fujii T and Kazanietz MG: Protein kinase C promotes apoptosis in LNCaP prostate cancer cells through activation of p38 MAPK and inhibition of the akt survival pathway. J Biol Chem 278: 33753-33762, 2003.

13. Newton AC: Protein kinase C: structure, function, and regulation. J Biol Chem 270: 28495-28498, 1995.

14. Way KJ, Chou E and King GL: Identification of PKC-isoformspecific biological actions using pharmacological approaches. Trends Pharmacol Sci 21: 181-187, 2000.

15. Morse-Gaudio M, Connolly JM and Rose DP: Protein kinase C and its isoforms in human breast cancer cells: Relationship to the invasive phenotype. Int J Oncol 12: 1349-1354, 1998.

16. Soh JW, Lee YS and Weinstein IB: Effects of regulatory domains of specific isoforms of protein kinase $\mathrm{C}$ on growth control and apoptosis in MCF-7 breast cancer cells. J Exp Ther Oncol 3: 115-126, 2003.

17. Frankel LB, Lykkesfeldt AE, Hansen JB and Stenvang J: Protein Kinase $\mathrm{C}$ alpha is a marker for antiestrogen resistance and is involved in the growth of tamoxifen resistant human breast cancer cells. Breast Cancer Res Treat 104: 165-179, 2007.

18. Tonetti DA, Chisamore MJ, Grdina W, Schurz H and Jordan VC: Stable transfection of protein kinase $\mathrm{C}$ alpha cDNA in hormonedependent breast cancer cell lines. Br J Cancer 83: 782-791, 2000. 
19. Blobe GC, Sachs CW, Khan WA, Fabbro D, Stabel S, Wetsel WC Obeid LM, Fine RL and Hannun YA: Selective regulation of expression of protein kinase $\mathrm{C}$ (PKC) isoenzymes in multidrugresistant MCF-7 cells. J Biol Chem 268: 658-664, 1993.

20. Shanmugam M, Krett NL, Maizels ET, Cutler RE Jr, Peters CA, Smith LM, O'Brien ML, Park-Sarge OK, Rosen ST and Hunzicker-Dunn M: Regulation of protein kinase C delta by estrogen in the MCF-7 human breast cancer cell line. Mol Cell Endocrinol 148: 109-118, 1999.

21. Kruger JS and Reddy KB: Distinct mechanisms mediate the initial and sustained phases of cell migration in epidermal growth factor receptor-overexpressing cells. Mol Cancer Res 1: 801-809, 2003

22. McCracken MA, Miraglia LJ, McKay RA and Strobl JS: Protein kinase $\mathrm{C}$ delta is a prosurvival factor in human breast tumor cell lines. Mol Cancer Ther 2: 273-281, 2003.

23. Grossoni VC, Falbo KB, Kazanietz MG, de Kier Joffé ED and Urtreger AJ: Protein kinase $\mathrm{C}$ delta enhances proliferation and survival of murine mammary cells. Mol Carcinog 46: 381-390, 2007.

24. Maizels ET, Shanmugam M, Lamm ML and Hunzicker-Dunn M: Hormonal regulation of PKC-delta protein and mRNA levels in the rabbit corpus luteum. Mol Cell Endocrinol 122: 213-221, 1996.

25. Fujii T, Nakamura AM, Yokoyama G, Yamaguchi M, Tayama K, Miwa K, Toh U, Kawamura D, Shirouzu K, Yamana H, et al: Antineoplaston induces G (1) arrest by PKC $\alpha$ and MAPK pathway in SKBR-3 breast cancer cells. Oncol Rep 14: 489-494, 2005

26. Liu JF, Crépin M, Liu JM, Barritault D and Ledoux D: FGF-2 and TPA induce matrix metalloproteinase-9 secretion in MCF-7 cells through PKC activation of the Ras/ERK pathway. Biochem Biophys Res Commun 293: 1174-1182, 2002.

27. Keshamouni VG, Mattingly RR and Reddy KB: Mechanism of 17-beta-estradiol-induced Erk 1/2 activation in breast cancer cells. A role for HER2 AND PKC-delta. J Biol Chem 277: 22558-22565, 2002.

28. Clark AS, West KA, Blumberg PM and Dennis PA: Altered protein kinase $\mathrm{C}$ (PKC) isoforms in non-small cell lung cancer cells: PKCdelta promotes cellular survival and chemotherapeutic resistance. Cancer Res 63: 780-786, 2003.

29. Zarubin T and Han J: Activation and signaling of the p38MAP kinase pathway. Cell Res 15: 11-18, 2005.

30. Reddy KB, Krueger JS, Kondapaka SB and Diglio CA: Mitogenactivated protein kinase (MAPK) regulates the expression of progelatinase B (MMP-9) in breast epithelial cells. Int J Cancer 82: 268-273, 1999.

31. Frost JA, Geppert TD, Cobb MH and Feramisco JR: A requirement for extracellular signal-regulated kinase (ERK) function in the activation of AP-1 by Ha-Ras, phorbol 12-myristate 13-acetate, and serum. Proc Natl Acad Sci USA 91: 3844-3848, 1994

32. Pagès G, Lenormand P, L'Allemain G, Chambard JC, Meloche S and Pouysségur J: Mitogen-activated protein kinases p42mapk and $\mathrm{p} 44 \mathrm{mapk}$ are required for fibroblast proliferation. Proc Natl Acad Sci USA 90: 8319-8323, 1993.

33. Zhang W and Liu H: MAPK signal pathways in the regulation of cell proliferation in mammalian cells. Cell Res 12: 9-18, 2002.

34. Lei X, Yang J, Nichols RW and Sun LZ: Abrogation of TGF $\beta$ signaling induces apoptosis through the modulation of MAP kinase pathways in breast cancer cells. Exp Cell Res 313: 1687-1695, 2007.

35. Peyssonnaux $\mathrm{C}$ and Eychène A: The Raf/MEK/ERK pathway: new concepts of activation. Biol Cell 93: 53-62, 2001.

36. Yan Y, Haas JP, Kim M, Sgagias MK and Cowan KH: BRCA1induced apoptosis involves inactivation of ERK1/2 activities. J Biol Chem 277: 33422-33430, 2002.

37. Duh JL, Yu R, Jiao JJ, Matwyshyn GA, Li W, Tan TH and Kong AN: Activation of signal transduction kinases by tamoxifen. Pharm Res 14: 186-189, 1997

38. Acconcia F and Kumar R: Signaling regulation of genomic and nongenomic functions of estrogen receptors. Cancer Lett 238: $1-14,2006$

39. Zheng A, Kallio A and Härkönen P: Tamoxifen-induced rapid death of MCF-7 breast cancer cells is mediated via extracellularly signal-regulated kinase signaling and can be abrogated by estrogen. Endocrinology 148: 2764-2777, 2007.

40. Katayama K, Yoshioka S, Tsukahara S, Mitsuhashi J and Sugimoto Y: Inhibition of the mitogen-activated protein kinase pathway results in the down-regulation of P-glycoprotein. Mol Cancer Ther 6: 2092-2102, 2007.

41. Mandlekar S and Kong AN: Mechanisms of tamoxifen-induced apoptosis. Apoptosis 6: 469-477, 2001.
42. Lamb JA, Ventura JJ, Hess P, Flavell RA and Davis RJ: Jun D mediates survival signaling by the JNK signal transduction pathway. Mol Cell 11: 1479-1489, 2003.

43. Park SK, Sanders BG and Kline K: Tocotrienols induce apoptosis in breast cancer cell lines via an endoplasmic reticulum stressdependent increase in extrinsic death receptor signaling. Breast Cancer Res Treat 124: 361-375, 2010.

44. Xia Z, Dickens M, Raingeaud J, Davis RJ and Greenberg ME: Opposing effects of ERK and JNK-p38 MAP kinases on apoptosis. Science 270: 1326-1331, 1995.

45. Schafer JM, Bentrem DJ, Takei H, Gajdos C, Badve S and Jordan VC: A mechanism of drug resistance to tamoxifen in breast cancer. J Steroid Biochem Mol Biol 83: 75-83, 2002.

46. Migliaccio A, Pagano M and Auricchio F: Immediate and transient stimulation of protein tyrosine phosphorylation by estradiol in MCF-7 cells. Oncogene 8: 2183-2191, 1993.

47. Dong YG, Chen DD, He GJ and Guan YY: Effects of 15-deoxydelta12, 14-prostaglandin J2 on cell proliferation and apoptosis in ECV304 endothelial cells. Acta Pharmacol Sin 25: 47-53, 2004.

48. Li C, Hu Y, Mayr M and Xu Q: Cyclic strain stress-induced mitogen-activated protein kinase (MAPK) phosphatase 1 expression in vascular smooth muscle cells is regulated by Ras/ Rac-MAPK pathways. J Biol Chem 274: 25273-25280, 1999.

49. Buytaert E, Dewaele M and Agostinis P: Molecular effectors of multiple cell death pathways initiated by photodynamic therapy. Biochim Biophys Acta 1776: 86-107, 2007.

50. Vessières A, Corbet C, Heldt JM, Lories N, Jouy N, Laïos I, Leclercq G, Jaouen G and Toillon RA: A ferrocenyl derivative of hydroxytamoxifen elicits an estrogen receptor-independent mechanism of action in breast cancer cell lines. J Inorg Biochem 104: 503-511, 2010.

51. Jun CD, Oh CD, Kwak HJ, Pae HO, Yoo JC, Choi BM, Chun JS, Park RK and Chung HT: Over-expression of protein kinase C isoforms protects RAW264.7 macrophages from nitric oxideinduced apoptosis: involvement of c-Jun N-terminal kinase/ stress-activated protein kinase, p38 kinase, and CPP-32 protease pathways. J Immunol 162: 3395-3401, 1999.

52. Greco S, Storelli C and Marsigliante S: Protein kinase C (PKC) $\delta / \varepsilon$ mediate the PKC/Akt-dependent phosphorylation of extracellular signal-regulated kinases 1 and 2 in MCF-7 cells stimulated by bradykinin. J Endocrinol 188: 79-89, 2006.

53. Mandil R, Ashkenazi E, Blass M, Kronfeld I, Kazimirsky G, Rosenthal G, Umansky F, Lorenzo PS, Blumberg PM and Brodie C: Protein kinase $\mathrm{C} \alpha$ and protein kinase $\mathrm{C} \delta$ play opposite roles in the proliferation and apoptosis of glioma cells. Cancer Res 61: 4612-4619, 2001

54. Capiati DA, Vazquez G, Tellez Iñón MT and Boland RL: Antisense oligonucleotides targeted against protein kinase $\mathrm{Ca}$ inhibit proliferation of cultured avian myoblasts. Cell Prolif 33 307-315, 2000

55. Bollag WB: Protein kinase Calpha puts the hand cuffs on epidermal keratinocyte proliferation. J Invest Dermatol 129: 2330-2332, 2009.

56. Matassa AA, Kalkofen RL, Carpenter L, Biden TJ and Reyland ME: Inhibition of PKC $\alpha$ induces a PKC $\delta$-dependent apoptotic program in salivary epithelial cells. Cell Death Differ 10: 269-277, 2003.

57. Wang WL, Yeh SF, Huang EY, Lu YL, Wang CF, Huang CY and Lin WJ: Mitochondrial anchoring of PKC $\alpha$ by PICK1 confers resistance to etoposide-induced apoptosis. Apoptosis 12: 1857-1871, 2007.

58. Ways DK, Kukoly CA, deVente J, Hooker JL, Bryant WO, Posekany KJ, Fletcher DJ, Cook PP and Parker PJ: MCF-7 breast cancer cells transfected with protein kinase $\mathrm{C}$-alpha exhibit altered expression of other protein kinase $\mathrm{C}$ isoforms and display a more aggressive neoplastic phenotype. J Clin Invest 95: 1906-1915, 1995.

59. Ruiz-Ruiz C, Robledo G, Font J, Izquierdo $M$ and López-Rivas A: Protein kinase C inhibits CD95 (Fas/APO-1)-mediated apoptosis by at least two different mechanisms in Jurkat T cells. J Immunol 163: 4737-4746, 1999 .

60. Whitehurst CE, Boulton TG, Cobb MH and Geppert TD: Extracellular signal regulated kinases in T cells. Anti-CD3 and 4 beta-phorbol 12-myristate 13- acetate-induced phosphorylation and activation. J Immunol 148: 3230-3237, 1992.

61. Lin CW, Yang LY, Shen SC and Chen YC: IGF-I plus E2 induces proliferation via activation of ROS-dependent ERKs and JNKs in human breast carcinoma cells. J Cell Physiol 212: 666-674, 2007.

62. Wu WS and Huang JM: Activation of protein kinase $\mathrm{C}$ alpha is required for TPA-triggered ERK (MAPK) signaling and growth inhibition of human hepatoma cell HepG2. J Biomed Sci 12: 289-296, 2005 